\title{
Simulasi Pemohonan Listrik (Electrical Treeing) pada Isolasi Polimer dengan Menggunakan Metode Cellular Automata
}

\author{
Suwarno \& Ronald P. Hutahaean \\ Departemen Teknik Elektro ITB, Jl. Ganesha 10 Bandung 40132 \\ e-mail: suwarno@ieee.org, Tel : 022-250-2260,Fax : 022-253-4222
}

\begin{abstract}
Abstrak. Akhir-akhir ini material polimer semakin banyak dipergunakan untuk isolasi kabel tegangan tinggi. Selama beroperasi isolasi mengalami medan tinggi dan dapat memunculkan degradasi dalam bentuk seperti pohon yang dikenal dengan pemohonan listrik. Kehadiran pemohonan listrik merupakan pertanda telah terjadi proses degradasi yang berbahaya yang dapat menyebabkan kegagalan isolasi. Agar kemunculan pemohonan listrik dapat dihindari dan supaya dapat mendiagnosis kondisi isolasi perlu diketahui perilaku pemohonan listrik dalam isolasi polimer. Paper ini menjelaskan hasil simulasi komputer terhadap perilaku pemohonan listrik dalam isolasi polimer menggunakan Cellular Automata. Kemunculan dan kecepatan propagasi pemohonan listrik sangat ditentukan oleh medan kritis isolasi. Dalam desain kabel perlu diperhatikan medan kritis isolasi polimer agar dapat menekan kemunculan dan propagasi pemohonan listrik.
\end{abstract}

Kata kunci: polimer; pemohonan listrik; simulasi; cellular automata.

Abstract. Recently, polymeric insulating materials are widely used for high voltage cables. During operation, a field enhancement sites such as void and protrusion may exist in the polymeric insulation. Degradation of the insulation may occur and the so-called electrical treeing will grow. The electrical treeing appears in the polymeric insulation in the form of tree-like structure with very fine cylindrical channels similar to the trunks and branches in an actual tree. The appearance of an electrical treeing is a sign that a harmful degradation is developing in the insulation. In order to avoid the electrical treeing to occur in the polymeric insulation and for diagnosing of the condition, it is important to know the behavior of the electrical treeing and the correlation with the insulation materials. This paper reports a computer simulation results of the behavior of the electrical treeing using Cellular Automata. The simulation was done in polymeric materials with various critical electric fields. The simulation results showed that selection of polymeric insulating materials with high critical field is a very important step in the design of insulation.

Keywords: polymer; electrical treeing; simulation; cellular automata. 


\section{Pendahuluan}

Material polimer saat ini telah banyak digunakan sebagai material isolasi pada peralatan listrik tegangan tinggi. Material polimer ini selain memiliki tegangan tembus yang tinggi, juga memiliki keuntungan seperti kekuatan dielektrik tinggi, ringan dan mudah dalam proses pembuatan ${ }^{1}$.

Tembus akibat peluahan ini (discharge breakdown) pada material isolasi polimer merupakan fenomena yang sangat penting dalam menentukan umur dari isolasi. Selain disebabkan oleh void dan material konduktif, tembus peluahan bergantung juga pada berbagai macam parameter, seperti konfigurasi elektroda, ketebalan dielektrik, temperatur, tekanan, sifat dan morfologi dari material $^{2}$.

Penelitian masalah pemohonan listrik biasanya dilakukan di laboratorium. Untuk mengetahui proses pemohonan listrik di dalam laboratorium dan mempelajari karakteristiknya merupakan proses yang memakan banyak waktu, memakan biaya yang banyak serta memerlukan peralatan yang sangat yang baik. Oleh karena itu simulasi pemohonan listrik pada komputer dapat dijadikan alat bantu untuk mengamati model fisik dari inisiasi pemohonan dan propagasinya.

Untuk implementasi simulasi dapat digunakan metoda fractal atau cellular automata $^{3,4}$. Pada makalah ini untuk implementasi simulasi digunakan metoda cellular automata karena lebih sederhana dibandingkan dengan metoda fractal mengingat tidak diperlukannya faktor fractal dimension.

\section{$2 \quad$ Pemohonan Listrik}

Pada pemakaian isolasi polimer sering ditemukan adanya gas yang terperangkap didalamnya. Secara umum, gas memiliki konstanta dielektrik yang kecil (mendekati 1) dibandingkan dengan konstanta dielektrik isolasi polimer (antara 2 - 6) sehingga gas akan mendapat kuat medan yang lebih besar dari isolasi polimer, padahal kekuatannya lebih rendah. Dengan demikian gas akan tembus pada saat isolasi polimer masih jauh dari tembus. Tembus gas dalam isolasi padat ini dinamakan peluahan sebagian (partial discharge) ${ }^{5}$.

Akibat peluahan sebagian di dalam void dapat tumbuh kanal bercabang-cabang membentuk suatu struktur menyerupai ranting-ranting pohon yang disebut pemohonan listrik (electrical treeing $)^{4,6}$. Pemohonan ini makin lama akan makin panjang yang akan menghubungkan elektroda atau bagian konduktor dengan konduktor lain. Bila hal ini terjadi maka biasanya isolasi polimer sudah tidak dapat lagi berfungsi untuk menahan medan normal. Pemohonan listrik juga 
dapat bermula dari medan yang sangat tinggi di dalam isolasi polimer karena adanya permukaan konduktor yang tajam atau ada kontaminan konduktif. Bila radius ketajaman $\mathrm{r}$, jarak elektroda $\mathrm{d}$ dan tegangan yang diterapkan $\mathrm{V}$ maka medan maksiumu telah diturunkan oleh Mason sebesar ${ }^{7,8}$

$$
E=\frac{2 V}{r \ln (4 \mathrm{~d} / \mathrm{r})}
$$

Medan lokal sebesar lebih dari $1 \mathrm{MV} / \mathrm{m}$ dapat muncul di daerah seperti ini. Degradasi lokal akibat stress medan listrik seperti ini akan menginisiasi munculnya pemohonan listrik. Untuk memperlambat waktu terjadinya pemohonan listrik dapat dilakukan dengan membuat isolasi sehomogen mungkin, untuk mecegah terjadinya rongga udara (void), membuat permukaan yang bersentuhan antara konduktor dengan isolasi sehalus mungkin sehingga tidak ada bagian yang menonjol, yang akan mengakibatkan terjadinya medan yang besar dan terpusat di satu titik.

Pemohonan listrik ditemukan pada isolasi polimer di daerah yang memiliki medan listrik yang tinggi, seperti pada ketidakrapian logam, kontaminan yang bersifat konduktor dan ketidakteraturan struktur. Peluahan sebagian yang terjadi di dalam void juga dapat menyebabkan pemohonan listrik karena void ini dapat menjadi sumber kedua untuk terbentuknya pemohonan listrik. Pemohonan listrik yang terbentuk pada sebuah elektroda disebut vented trees (pemohonan berventilasi), sementara pemohonan yang tumbuh pada tubuh isolasi yang memiliki struktur kanal bercabang yang kasar yang berorientasi sepanjang garis-garis medan disebut bow-tie trees ${ }^{9}$.

Tidak semua vented trees memiliki bentuk yang sama. Ada tiga sub kategori bentuk pemohonan listrik yang secara kasar dapat dibedakan sebagai ${ }^{2}$ :

- branch type tree,

- bush type tree,

- dan bush-branch type tree.

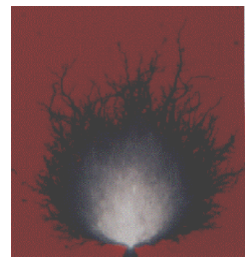

(a)

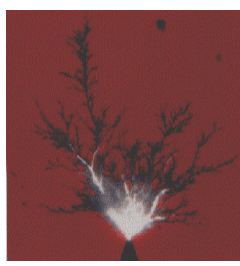

(b)

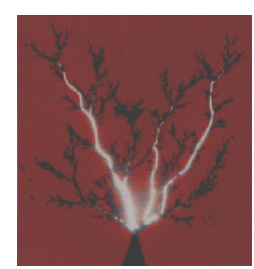

(c)

Gambar 1 Ilustrasi bentuk dari pemohonan listrik: (a) Bush type tree, (b) BushBranch type tree, dan (c) Branch type tree. 


\section{$3 \quad$ Simulasi}

\subsection{Cellular Automata}

Cellular automata pertama kali diperkenalkan oleh John von Neumann sekitar tahun 1940-an dan telah digunakan secara luas sebagai model untuk menyelesaikan sistem yang kompleks. Cellular automata (selanjutnya disingkat CA) adalah suatu model dari sistem fisik dimana ruang dan waktu adalah diskrit dan interaksi yang terjadi bersifat lokal. Disamping kesederhanaan strukturnya, CA juga dapat digunakan untuk memperlihatkan fenomena kompleks yang dinamis dan dapat menerangkan berbagai macam proses dan sistem fisik ${ }^{10,11}$.

CA terdiri dari satu, dua atau n-dimensi array yang terdiri dari sel-sel yang seragam dan tetap. Biasanya dipergunakan CA satu atau dua dimensi karena kesulitan dalam memvisualisasikan model dengan dimensi yang lebih tinggi. Sel-sel tersebut merupakan representasi dari sistem fisik dan masing-masing sel memiliki nilai. Sel-sel tersebut akan berinteraksi secara lokal dengan tetanggatetangganya. Ada dua macam model dari CA dua dimensi, yakni von Neumann neighborhood dan Moore neighborhood seperti pada gambar 1. Pada model Von Neumann neighborhood sebuah sel terdiri dari empat sel tetangga yang berada pada arah utara $(\mathrm{N})$, timur $(\mathrm{E})$, selatan $(\mathrm{S})$, dan barat $(\mathrm{W})$, sedangkan model Moore neighborhood terdiri dari delapan sel tetangga dengan tambahan di arah barat laut (NE), tenggara (SE), barat daya (SW), dan timur laut (NW).

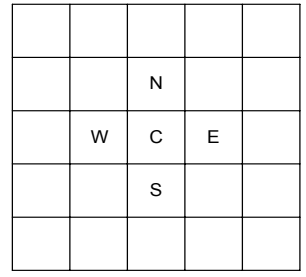

(a)

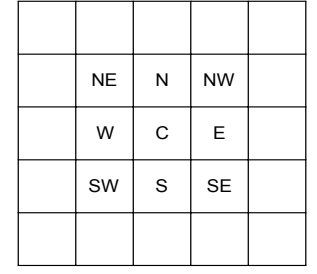

(b)

Gambar 2 (a) Von Neumann dan (b) Moore neighborhood.

Keadaan (state) tiap sel akan diperbaharui secara serentak pada tiap time step berdasarkan kondisi sel itu sendiri dan sel-sel tetangganya pada time step sebelumnya. Algoritma yang digunakan untuk menghitung kondisi dari sel selanjutnya ditentukan oleh suatu aturan-aturan yang disebut CA local rule. Biasanya local rule yang sama diterapkan di semua sel pada CA. Secara umum CA setidaknya harus memiliki empat hal di bawah ini:

1. Jumlah dimensi array $(n)$

2. Lebar sisi array $(w), w_{j}$ adalah lebar dari sisi ke-j array, dimana $j=1,2,3 . . n$ 
3. Lebar dari sel $(d)$

4. CA local rule yang ditentukan oleh fungsi $F$ sembarang.

State dari sel pada time step $(t+1)$ dihitung berdasarkan fungsi $F$. $F$ adalah fungsi dari state sel dan state dari tetangga-tetangganya pada time step $(t)$. Sebagai contoh, misalkan sebuah CA dua dimensi dengan $d_{1}=d_{2}$ seperti pada gambar 3.

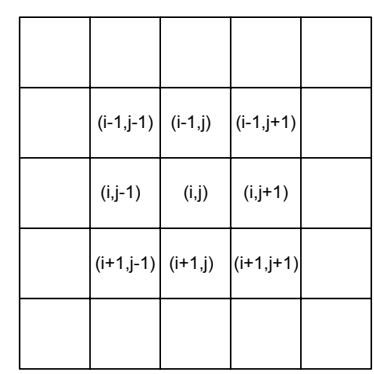

Gambar 3 Cellular automata dua dimensi.

Pada contoh ini sel $(i, j)$ terdiri dari delapan sel tetangga yang berdekatan. CA local rule yang akan digunakan untuk menghitung sel $(i, j)$ pada time step $t+1$ merupakan fungsi dari keadaan sel $(i, j)$ itu sendiri dan keadaan sel-sel pada time step t. Jadi,

$$
C_{i, j}^{t+1}=F\left(C_{i-1, j-1}^{t}, C_{i-1, j}^{t}, C_{i-1, j+1}^{t}, C_{i, j-1}^{t}, C_{i, j}^{t}, C_{i, j+1}^{t}, C_{i+1, j-1}^{t}, C_{i+1, j}^{t}, C_{i+1, j+1}^{t}\right)
$$

$C_{i, j}^{t}$ dan $C_{i, j}^{t+1}$ adalah keadaan sel $(i, j)$ pada time step $t$ dan $t+1$.

\subsection{Finite difference Method}

Dalam simulasi ini algoritma yang dipergunakan untuk menghitung distribusi potensial pada dielektrik padat adalah finite difference method ${ }^{12}$.

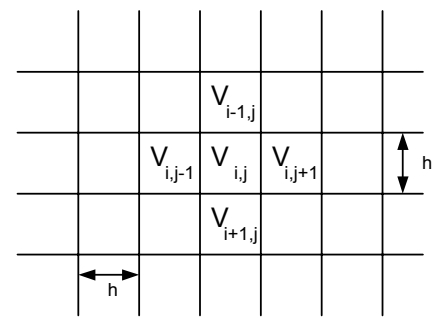

Gambar 4 Bagian daerah yang berisi potensial dua dimensi. 
Dengan memandang persoalan dua-dimensi yang potensialnya tidak berubah terhadap koordinat $\mathrm{z}$, bagian dari penampang isolasi padat dibagi menjadi selsel bujur sangkar dengan panjang sisi h. Sebagian dari daerah tersebut digambarkan pada gambar 4. Harga-harga yang tidak diketahui pada lima sel yang berdekatan ditunjukkan sebagai $V_{i, j}, V_{i+1, j}, V_{i, j+1}, V_{i-1, j}, V_{i, j-1}$.

Dengan menggunakan persamaan Laplace didapat bahwa :

$$
V_{i, j}=\frac{1}{4}\left[V_{i+1, j}+V_{i, j+1}+V_{i-1, j}+V_{i, j+1}\right]
$$

Untuk mendapatkan perhitungan yang lebih baik lagi digunakan metode iterasi untuk menentukan potensial pada tiap sel bujur sangkar sebagian secara bergilir, dan kemudian prosesnya diulang ke seluruh daerah berkali-kali sehingga harga potensial tersebut tidak berubah lagi. Pada awal iterasi, potensial awal $V_{i, j}^{0}$ ditentukan dan pada simulasi ini nilai potensial awal ditentukan sama dengan nol untuk menyederhanakan program.. Setelah nilai awal ditentukan maka nilai aproksimasi potensial pertama $V_{i, j}^{1}$ dihitung dengan persamaan (3). Demikian seterusnya sampai potensial semua sel bujur sangkar dihitung.

\subsection{Proses Simulasi}

Kondisi (state), $C_{i, j}^{t}$ dari sel $(i, j)$ (gambar 3) pada time step $t$ adalah:

$$
C_{i, j}^{t}=\left\{E F_{i, j}, T F_{i, j}, E_{i, j}^{t}, V_{i, j}^{t}\right\}
$$

$E F_{i, j}$ adalah electrode flag. Nilai tersebut menunjukkan kondisi sel sebagai elektroda atau dielektrik padat. Jika $E F_{i, j}=1$ maka sel $(i, j)$ merupakan salah satu dari elektroda, tetapi jika $E F_{i, j}=0$ maka sel $(i, j)$ merupakan dielektrik padat. $T F_{i, j}=$ merupakan tree flag dan menunjukkan kondisi sel sebagai struktur pemohonan listrik atau bukan. Jika $T F_{i, j}=1$ maka sel $(i, j)$ merupakan bagian dari struktur pemohonan listrik, tetapi jika $T F_{i, j}=0$ maka sel $(i, j)$ bukan merupakan bagian struktur pemohonan listrik. Sedangkan $E_{i, j}^{t}$ adalah nilai dari medan listrik lokal dari sel $(i, j)$. Medan listrik untuk elektroda adalah -1 . Nilai ini tidak memiliki arti fisik akan tetapi digunakan untuk menghindari kesalahan selama pengeksekusian program komputer. Potensial yang menunjukkan elektroda plat adalah sama dengan nol sedangkan potensial dari elektroda jarum adalah $V_{a p}$. 
Untuk perhitungan medan listrik di masing-masing sel (misal sel $(i+1, j+1))$ saat simulasi, digunakan persamaan:

$$
E_{i+1, j+1}^{t}=\varepsilon_{i+1, j+1} \frac{V_{i+1, j+1}^{t}}{a_{i+1, j+1}}
$$

dimana $\varepsilon_{i+1, j+1}$ adalah permitivitas material pada sel $(i+1, j+1)$, nilai permitivitas ini merupakan nilai random dari 2,1 - 2,25 yang merepresentasikan ketidakhomogenan dielektrik polyethylene. $V_{i+1, j+1}^{t}$ adalah potensial pada sell $(i+1, j+1)$ pada time step $t$ yang merupakan beda tegangan antara elektroda ujung jarum $\left(V_{a p}\right)$ dengan sel $(i+1, j+1)$. Sedangkan $a_{i+1, j+1}$ adalah jarak antara sel $(i+1, j+1)$ dengan sel $(i, j)$.

Untuk mensimulasikan propagasi pemohonan listrik, $C A$ rule seperti di bawah ini:

1. Jika tree flag dari sel $(i, j), T F_{i, j}$, pada time step $(t)$ adalah 1 , maka sel tersebut tidak akan berubah pada time step $(t+1)$.

2. Jika tree flag dari sel $(i, j), T F_{i, j}$, pada time step $(t)$ adalah 0 , dan tidak ada nilai tree flag tetangga dari sel yang sama dengan 1 , maka sel tersebut tidak akan berubah pada time step $(t+1)$.

3. Jika tree flag dari sel $(i, j), T F_{i, j}$, pada time step $(t)$ adalah 0 , dan satu atau lebih nilai tree flag tetangga dari sel adalah 1 , maka sel $(i, j)$ tadi berubah menjadi 1 pada time step $(t+1)$, hanya jika kuat medan lokalnya melebihi nilai kuat medan kritis $\left(E_{c}\right)$ dari material.

\section{$4 \quad$ Hasil Simulasi dan Analisis}

\subsection{Pemohonan Listrik pada Tegangan $8 \mathrm{kV}$ dengan $E_{c}=2.25 x$ $10^{7} \mathrm{~V} / \mathrm{m}$}

Gambar 5 menunjukkan hasil simulasi pemohonan listrik pada tegangan $8 \mathrm{kV}$ dengan medan kritis $E_{c}=2.25 \times 10^{7} \mathrm{~V} / \mathrm{m}$ hingga $\mathrm{t}=30$. Dari simulasi didapatkan bahwa pada saat $t=5$ persentase pertumbuhan dari pemohonan listrik adalah sebesar sekitar $25 \%$ dari jarak antara elektroda jarum dengan elektroda plat. Akan tetapi dengan telah terjadinya pemohonan listrik maka beberapa sel yang semula adalah bagian dari sel material akan berubah menjadi bagian sel dari pemohonan listrik. Perubahan tersebut akan menyebabkan potensial sel berubah menjadi tegangan masukan yaitu $8 \mathrm{kV}$. Perubahan potensial menyebabkan distribusi potensial kuat medan di sel. Apabila kuat medan 
tersebut melebihi nilai kekuatan dielektrik lokal maka akan terjadi lagi pemohonan listrik. Dari gambar 5 (b) untuk time step $(t)=10$ pertumbuhan listrik akan mencapai pertumbuhan sekitar $40 \%$ dari jarak antar elektroda jarum-plat. Pada time step $(t)=15$ pertumbuhan listrik mencapai sekitar $51 \%$ dari jarak antar elektroda jarum-plat. Pada time step 20 pemohonan listrik juga mencapai sekitar $51 \%$ dari jarak antar elektroda akan tetapi dari gambar terlihat cabang-cabang terlihat semakin banyak hal ini menunjukkan bahwa tembus yang terjadi pada material tidak hanya berpropagasi ke arah elektroda plat saja akan tetapi dapat juga terjadi propagasi antar sel yang merupakan bagian dari kanal pemohonan listrik.

Pada step 25 dan step 30 terjadi juga hal tersebut. Dimana pada step 25 dan 30 pertumbuhan listrik juga mencapai sekitar $72 \%$ dari jarak antar elektroda jarum-plat. Akan tetapi dari gambar terlihat pula bahwa cabang-cabang yang terjadi semakin banyak karena propagasi yang terjadi juga merupakan propagasi antar sel.

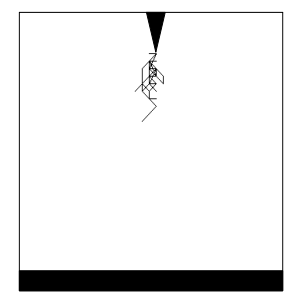

(a) $t=5$

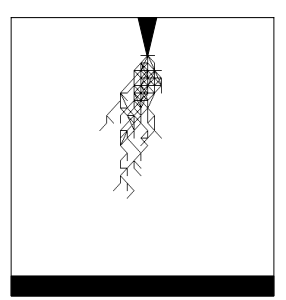

(d) $t=20$

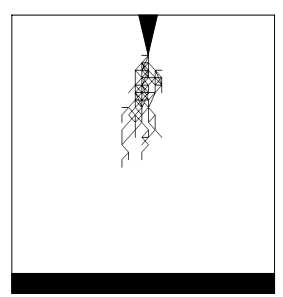

(b) $t=10$

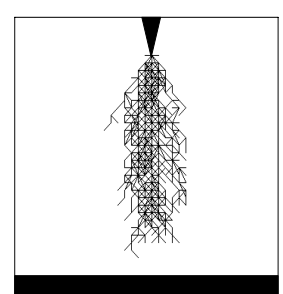

(e) $t=25$

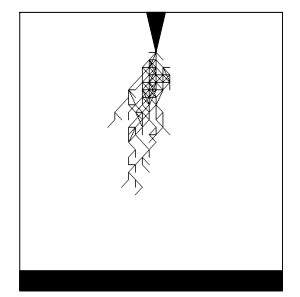

(c) $t=15$

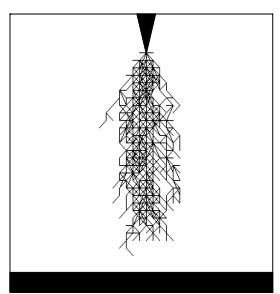

(f) $t=30$

Gambar 5 Pemohonan listrik pada tegangan $8 \mathrm{kV}$.

\subsection{Pemohonan Listrik pada Tegangan $10 \mathrm{kV}$ dengan $E_{c}=2.25 \mathrm{x}$ $10^{7} \mathrm{~V} / \mathrm{m}$}

Gambar 6 menunjukan simulasi yang dilakukan dengan menggunakan tegangan $10 \mathrm{kV}$ dengan $E_{c}=2.25 \times 10^{7} \mathrm{~V} / \mathrm{m}$. Pada tegangan ini saat time step $=2$ pemohonan listrik telah mencapai persentasi sekitar $10 \%$. Pada saat time step $=$ 4, pertumbuhan pemohonan listrik telah mencapai sekitar $26 \%$. 
Pada simulasi ini pertumbuhan pemohonan listrik terjadi sangat cepat bila dibandingkan dengan simulasi pada sebelumnya ketika tegangan $8 \mathrm{kV}$. Hal tersebut terlihat juga pada step-step selanjutnya dimana pada saat baru mencapai step yang keenam pertumbuhan pemohonan listrik telah mencapai persentase sekitar $51 \%$ dan pada step yang kedelapan pettumbuhan tersebut telah mencapai sekitar $75 \%$ dan cabang-cabang yang terjadi juga akan semakin banyak. Bila dibandingkan lagi dengan simulasi yang dilakukan pada saat $8 \mathrm{kV}$ maka kenaikan tegangan pada elektroda jarum berpengaruh terhadap pertumbuhan pemohonan listrik.

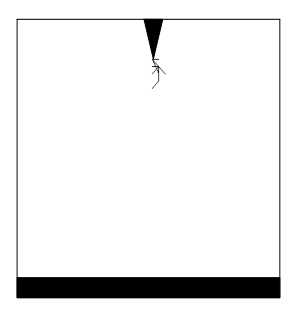

(a) $t=2$

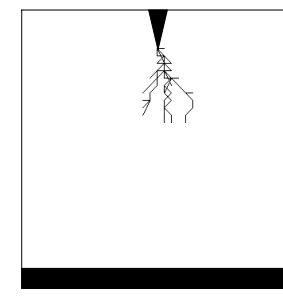

(b) $t=4$

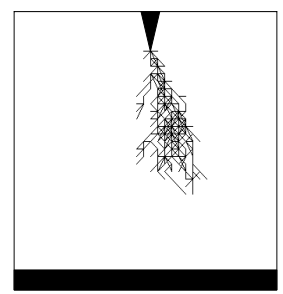

(c) $\mathrm{t}=6$

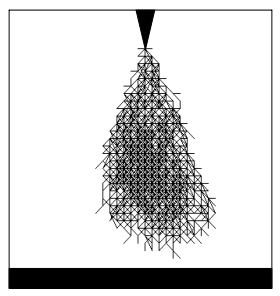

(d) $t=8$

Gambar 6 Pemohonan listrik pada tegangan $10 \mathrm{kV}$.

\subsection{Pemohonan Listrik pada Tegangan $12 \mathrm{kV}$ dengan $\mathrm{E}_{\mathrm{c}}=2.25 \mathrm{x}$ $10{ }^{7} \mathrm{~V} / \mathrm{m}$}

Pada gambar 7 simulasi dilakukan dengan menggunakan tegangan $12 \mathrm{kV}$. Pada time step $=1$ pertumbuhan pemohonan listrik telah telah mencapai persentase 10 $\%$ dari jarak antar elektroda jarum-plat.

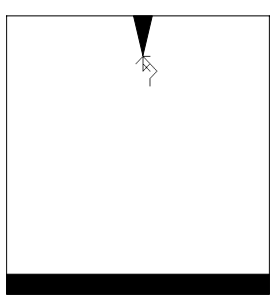

(a) $t=1$

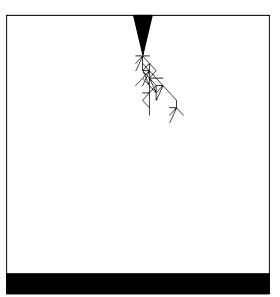

(b) $t=2$

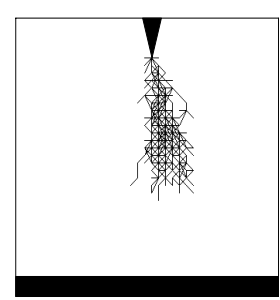

(c) $t=3$

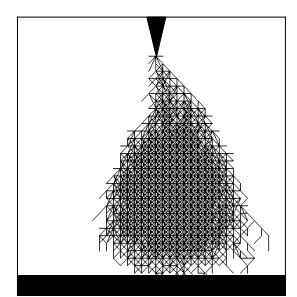

(d) $t=4$

Gambar 7 Pemohonan listrik pada tegangan $12 \mathrm{kV}$.

Pada time step $=2$ persentase pertumbuhan pemohonan listrik telah mencapai $25 \%$ akan tetapi pada time step berikutnya, yaitu time step $=3$, persentasenya meninkan menjadi dukalinya, yaitu sekitar $51 \%$. Hal ini juga terlihat pada time step $=4$, persentase pertumbuhan akan bertumbuh dengan cepat, bahkan pertumbuhan pemohonan listrik tersebut telah mencapai elektroda plat sehingga 
dapat dikatakan telah terjadi tembus pada material dielektrik. Pertumbuhan pemohonan listrik ini juga dibarengi dengan peningkatan jumlah cabang yang semakin banyak pula.

\subsection{Pemohonan Listrik pada Tegangan $20 \mathrm{kV}$ dengan $\mathrm{E}_{\mathrm{c}}=2.25 \mathrm{x}$ $10^{7} \mathrm{~V} / \mathrm{m}$}

Gambar 8 menunjukkan hasil simulasi pada tegangan tegangan $20 \mathrm{kV}$ untuk material dengan $\mathrm{E}_{\mathrm{c}}=2.25 \times 10^{7} \mathrm{~V} / \mathrm{m}$. Pada saat step $=1$, persentase pertumbuhan berada pada kisaran $44 \%$ dan padasaat step $=2$, pemohonan listrik telah menjembatani elektroda artinya isolasi telah mengalami kegagalan. Pertumbuhan pemohonan listrik ini juga diikuti dengan bertambah banyaknya cabang-cabang .

Dari hasil simulasi terlihat bahwa pemohonan listrik akan muncul pada ujung dari elektroda jarum dengan satu atau beberapa kanal. Kanal-kanal ini akan berkembang ke arah yang memiliki kuat medan yang paling lemah. Kecepatan terjadinya kegagalan isolasi semakin tinggi pada tegangan yang semakin besar.

Kenaikan dari tegangan yang diberikan pada elektroda jarum akan menaikkan medan di ujung elektroda jarum dan menaikkan medan disekitarnya. Dengan adanya kenaikan tegangan kemungkinan bertambahnya jumlah kanal-kanal pemohonan listrik semakin besar sehingga struktur pemohonan listrik yang terjadi akibat kenaikan tegangan akan seperti bush. Dari gambar terlihat bahwa dengan adanya kenaikan tegangan akan muncul banyak kanal-kanal dan dengan semakin tingginya kenaikan dari tegangan waktu isolasi untuk menjadi tembus semakin cepat. Walaupun dalam simulasi waktu step tidak menunjukkan waktu sebenarnya akan tetapi waktu step tersebut dapat digunakan untuk merepresentasikan waktu yang sebenarnya.

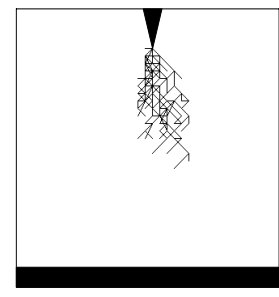

(a) $t=1$

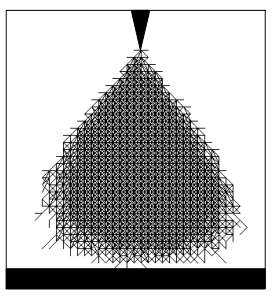

(b) $t=2$

Gambar 8 Pemohonan listrik pada tegangan $20 \mathrm{kV}$. 


\subsection{Pemohonan Listrik pada Tegangan $8 \mathrm{kV}$ dengan $E_{\mathrm{c}}$ berbeda $(t=15)$}

Gambar 9 menunjukkan hasil simulasi pemohonan listrik pada material yang memiliki kekuatan dielktrik yang berbeda pada tegangan $8 \mathrm{kV}$ hingga time step $=5$.

Dari gambar terlihat bahwa pertumbuhan pemohonan listrik akan menjadi lambat dengan adanya kenaikan kekuatan dielektrik pada tegangan yang sama.

Pada gambar 9(a) pertumbuhan pemohonan listrik pada material telah mencapai $51 \%$ dari jarak antar elektroda jarum-plat . Pada gambar 9(b) pertumbuhan pemohonan listrik dapat mencapai $32 \%$. Pada gambar 9(c) persentase sekitar 19 $\%$, pada gambar 9(d) persentase sekitar $17 \%$, pada gambar 9(e) persentase sekitar $10 \%$ dan pada gambar 9 (f) persentase sekitar 5,3\%.

Penurunan persentase ini menunjukkan bahwa dengan tegangan yang diberikan pada elektroda jarum sebesar $8 \mathrm{kV}$, material masih mampu menahan kuat medan yang ditimbulkan oleh ujung jarum sehingga pertumbuhan pemohonan listrik tidak berlanjut sampai terjadi tembus.

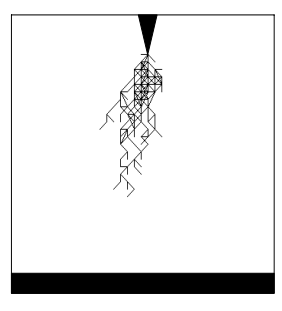

(a) $\mathrm{E}_{\mathrm{c}}=2.25 \times 10^{7} \mathrm{~V} / \mathrm{m}$

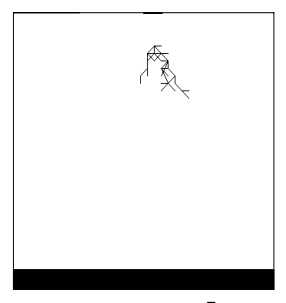

(d) $E_{c}=3 \times 10^{7} \mathrm{~V} / \mathrm{m}$

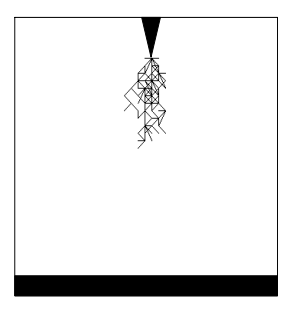

(b) $\mathrm{E}_{\mathrm{c}}=2.5 \times 10^{7} \mathrm{~V} / \mathrm{m}$

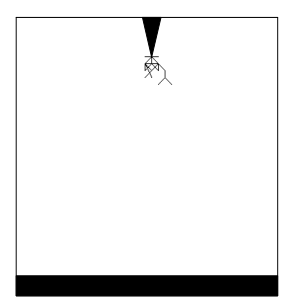

(e) $E_{c}=3.25 \times 10^{7} \mathrm{~V} / \mathrm{m}$

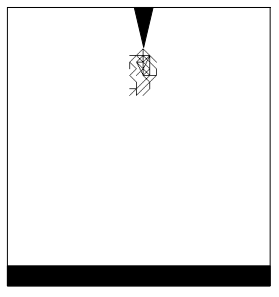

(c) $\mathrm{E}_{\mathrm{c}}=2.75 \times 10^{7} \mathrm{~V} / \mathrm{m}$

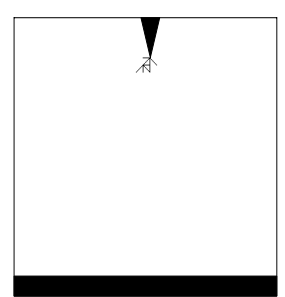

(f) $\mathrm{E}_{\mathrm{c}}=3.5 \times 10^{7} \mathrm{~V} / \mathrm{m}$

Gambar 9 Pemohonan listrik pada tegangan $8 \mathrm{kV}$ dengan $\mathrm{E}_{\mathrm{c}}$ berbeda. 


\subsection{Pemohonan Listrik pada Tegangan $12 \mathrm{kV}$ dengan $\mathrm{E}_{\mathrm{c}}$ berbeda $(t=5)$}

Gambar 10 menunjukkan hasil simulasi pada tegangan $12 \mathrm{kV}$ hingga $\mathrm{t}=5$. Dari gambar terlihat bahwa pada saat tegangan diberikan pada material dengan kekuatan dielektrik $2.25 \times 10^{7} \mathrm{~V} / \mathrm{m}$, material tersebut tidak mampu menahan medan yang tinggi yang pertama kali ditimbulkan pada ujung elektroda jarum.

Akan tetapi pada material-material berikutnya , material-material tersebut masih mampu menahan medan yang ditimbulkan oleh ujung elektroda jarum setidaknya selama 5 time step.

Seperti terlihat pada gambar 10(b) pertumbuhan pemohonan listrik dapat mencapai $65 \%$. Pada gambar 10 (c) persentase sekitar $50 \%$, pada gambar $10(\mathrm{~d})$ persentase sekitar $30 \%$, pada gambar 10(e) persentase sekitar $30 \%$ dan pada gambar 10(f) persentase sekitar $10 \%$.

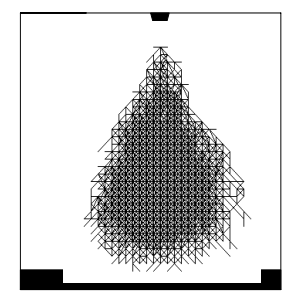

(a) $\mathrm{E}_{\mathrm{c}}=2.25 \times 10^{7} \mathrm{~V} / \mathrm{m}$

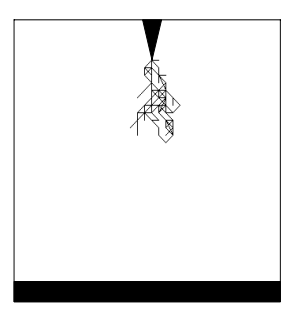

(d) $\mathrm{E}_{\mathrm{c}}=3 \times 10^{7} \mathrm{~V} / \mathrm{m}$

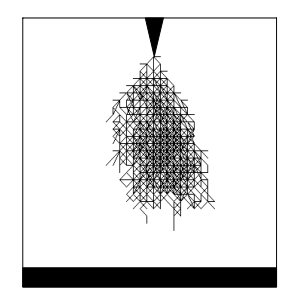

(b) $\mathrm{E}_{\mathrm{c}}=2.5 \times 10^{7} \mathrm{~V} / \mathrm{m}$

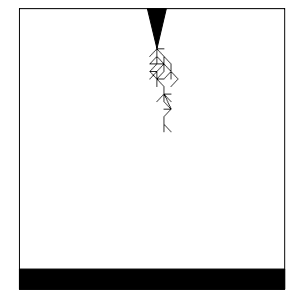

(e) $\mathrm{E}_{\mathrm{c}}=3.25 \times 10^{7} \mathrm{~V} / \mathrm{m}$

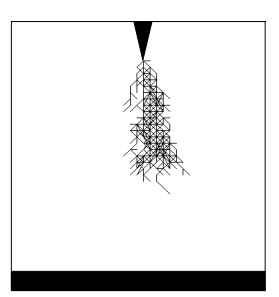

(c) $\mathrm{E}_{\mathrm{c}}=2.75 \times 10^{7} \mathrm{~V} / \mathrm{m}$

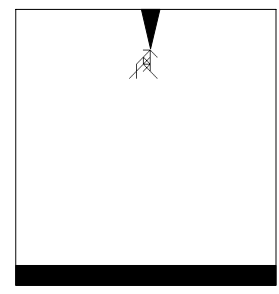

(f) $\mathrm{E}_{\mathrm{c}}=3.5 \times 10^{7} \mathrm{~V} / \mathrm{m}$

Gambar 10 Pemohonan listrik pada tegangan $12 \mathrm{kV}$ dengan $\mathrm{E}_{\mathrm{c}}$ berbeda.

\subsection{Pemohonan Listrik pada Tegangan $20 \mathrm{kV}$ dengan $\mathrm{E}_{\mathrm{c}}$ berbeda $(t=2)$}

Gambar 11 memperlihatkan hasil simulasi pada tegangan $20 \mathrm{kV}$. Dari gambar terlihat bahwa pada saat tegangan diberikan pada material dengan kekuatan 
dielektrik $2.25 \times 10^{7} \mathrm{~V} / \mathrm{m}$, material tersebut tidak mampu menahan medan yang tinggi yang pertama kali ditimbulkan pada ujung elektroda jarum.

Pada gambar 11(b) pertumbuhan pemohonan listrik dapat mencapai $72 \%$. Pada gambar 11(c) persentase sekitar $67 \%$, pada gambar 11(d) persentase sekitar 61 $\%$, pada gambar 11(e) persentase sekitar $46 \%$ dan pada gambar 11(f) persentase sekitar $20 \%$.

Dari hasil yang telah disimulasikan pada berbagai macam material terlihat bahwa tegangan sangat berpengaruh terhadap proses pertumbuhan pemohonan listrik karena dengan adanya kenaikan tegangan yang diberikan pada elektroda jarum maka akan timbul kuat medan yang sangat tinggi pada ujung elektroda dan seringkali kuat medan yang timbul pada ujung elektroda ini akan memunculkan pemohonan listrik. Akan tetapi kondisi dari material juga berpengaruh, hal tersebut terlihat pada hasil simulasi yang menunjukkan bahwa pada material yang memiliki kekuatan dielektrik yang besar ternyata mampu juga untuk menahan kuat medan yang timbul pada ujung elektroda jarum walaupun dalam simulasi hanya dilakukan untuk beberapa time step.

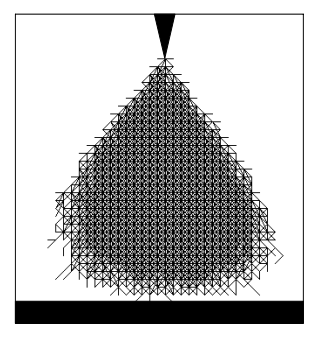

(a) $\mathrm{E}_{\mathrm{c}}=2.25 \times 10^{7} \mathrm{~V} / \mathrm{m}$

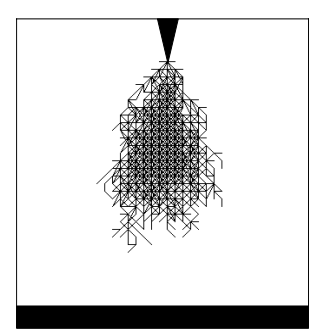

(d) $E_{c}=3 \times 10^{7} \mathrm{~V} / \mathrm{m}$

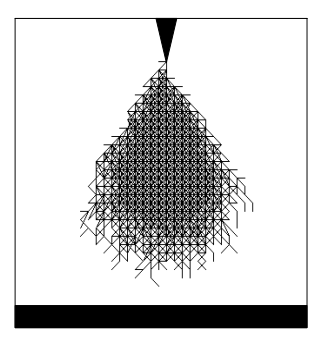

(b) $\mathrm{E}_{\mathrm{c}}=2.5 \times 10^{7} \mathrm{~V} / \mathrm{m}$

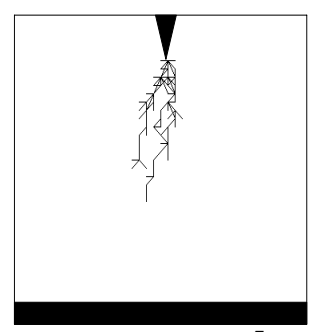

(f) $\mathrm{E}_{\mathrm{c}}=3.25 \times 10^{7} \mathrm{~V} / \mathrm{m}$

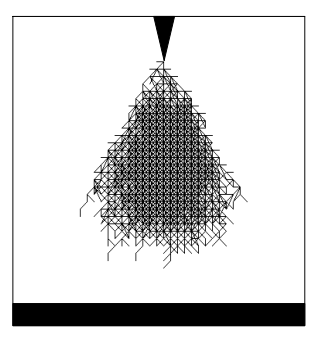

(c) $\mathrm{E}_{\mathrm{c}}=2.75 \times 10^{7} \mathrm{~V} / \mathrm{m}$

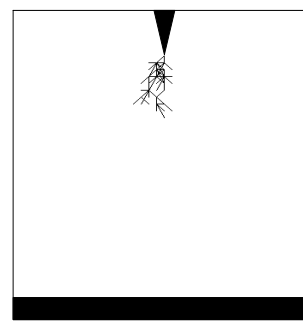

(g) $\mathrm{E}_{\mathrm{c}}=3.5 \times 10^{7} \mathrm{~V} / \mathrm{m}$

Gambar 11 Pemohonan listrik pada tegangan $20 \mathrm{kV}$ untuk berbagai material dengan medan kritis berbeda.

Dari simulasi didapatkan bahwa kenaikan tegangan menaikkan medan di ujung elektroda jarum dan menaikkan medan disekitarnya. Dengan adanya kenaikan 
tegangan kemungkinan bertambahnya jumlah kanal-kanal pemohonan listrik semakin besar sehingga struktur pemohonan listrik yang terjadi akibat kenaikan tegangan akan seperti bush.

Kenaikan tegangan juga sangat berpengaruh terhadap proses pertumbuhan pemohonan listrik. Hal ini desebabkan karena terjadi kenaikan kuat medan pada ujung elektroda yang memungkinkan memunculkan pemohonan listrik. Kondisi dari material juga berpengaruh. Hal ini terlihat pada hasil simulasi yang menunjukkan bahwa pada material yang memiliki kekuatan dielektrik yang besar ternyata mampu menahan kuat medan yang timbul pada ujung elektroda jarum sehingga pemohonan listrik tidak terjadi. Pola-pola pemohonan listrik hasil simulasi menunjukkan perilaku pengaruh waktu dan tegangan yang serupa dengan hasil eksperimen sebagaimana dilaporkan oleh Suwarno ${ }^{13}$.

\section{$5 \quad$ Kesimpulan}

Setelah melakukan pembahasan di atas, dapat disimpulkan beberapa hal sebagai berikut:

1. Simulasi pemohonan listrik dengan menggunakan Cellular Automata memberikan hasil yang baik dan memberikan perilaku yang serupa dengan hasil eksperimen.

2. Hasil simulasi menunjukkan bahwa kenaikan dari tegangan yang diberikan pada elektroda jarum akan menyebabkan kenaikan jumlah kanal-kanal pemohonan listrik dan membuat struktur pemohonan listrik menjadi seperti bush.

3. Semakin tinggi tegangan diterapkan semakin cepat terjadinya breakdown.

4. Semakin besar nilai kekuatan dielektrik material $\left(E_{c}\right)$ semakin lambat pertumbuhan pemohonan listrik.

\section{Daftar Pustaka}

1. Shugg, Tillar, Handbook of Electrical and Electronic Insulating Materials, $\mathbf{2}^{\text {nd }}$ ed., IEEE Press, (1995)

2. Dissado, L. A. \& Fothergill, J. C., Electrical Degradation And Breakdown In Polymers, Peter Peregrinus Ltd (1992)

3. Femin, N., Niemeyer, L., Tucci, V., Fractal Characteristics of Electrical Discharges: Experimens and Simulation, J. Phys. D: Appl. Phys., Vol. 26 (1993), pp. 619-627.

4. Danikas, M. G., Karafyllidis, I., Thanailakis, A. \& Burning, A. M., Simulation of electrical growth in solid dielectrics containing voids of arbitrary shape, Modelling simulation. Mater.Science engineering (1996) pp. 535-552 
5. Suwarno, Suzuoki, Y., Mizutani, T., "Partial discharge due to electrical treeing in polymers", Journal Applied Physics D: Applied Physics, December (1996 ) pp. 2922-2931

6. Kitchin, D. W. \& Pratt, O. S., Treeing in Polyethylene as a prelude to Breakdown, AIEEpt III, No. 35 (1958) pp. 180-186.

7. Mason, J. H., Deterioration and Breakdown of Dielectrics Resulting from Internal Discharges, Proc. IEE, Vol. 98, Part I (1951) pp. 44-59.

8. Mason, J. H., Breakdown of Soild Dielectric in Divergent Fields, IEE Monograph 127 M, 102 C, (1955) pp. 254-263.

9. Noskov, M. D., Malinovski, A. S., Sack, M. \& Schwab, A. J., SelfConsistent Modeling of Electrical Tree Propagation and PD Activity, IEEE Transactions on Dielectrics and Electrical Insulation (2000)

10. Weimar, Jorg R. Simulation with Cellular Automata, http://www.tubs.de/institute/WiR/weimar/ZAscript/ZAscript.html, (2000)

11. Worsch, Thomas, Programming enviroment for cellular automata, Departement of informatics, University of Karlshruhe(1996)

12. Zhou, Pei-bai, Numerical Analysis of Electromagnetic Fields, SpringerVerlag Berlin Heidelberg (1993)

13. Suwarno, Suzuoki, Y., Mizutani, T., Uchida, K., Partial Discharge Pattern Changes due to Electrical Tree Growth in Polyethylene, Transaction Institute of Electrical Engineers, Japan, No.11 (1995). 